\title{
REMEDIASI TANAH TERCEMAR LOGAM BERAT DENGAN MENGGUNAKAN BIOCHAR
}

\section{REMEDIATION OF CONTAMINATED SOIL BY USING BIOCHAR}

\author{
Benny Hidayat ${ }^{1 *}$ \\ ${ }^{1}$ Departemen Agroteknologi Fakultas Pertanian USU Medan- 20155 \\ *Corresponding author : bendayat@gmail.com
}

\begin{abstract}
ABSTRAK
Pembangunan industri dan urbanisasi selain dapat meningkatkan kesejahteraan manusia, tetapi juga memberikan efek negatif kepada lingkungan yaitu menghasilkan limbah dalam jumlah yang sangat besar, dan hal ini akan menjadi masalah yang serius bila tidak tangani dengan segera. Penangangan limbah pun masih belum di lakukan dengan serius dan bertanggung jawab sehingga sering dilaporkan adanya lahan yang tercemar akan limbah khususnya limbah logam berat. Logam- logam berat merupakan unsur yang tidak biodegradable sehingga limbah- limbah yang mengandung logam berat bila tertumpah ke lingkungan sedikit demi sedikit akan terakumulasi pada tanah dan air, bila ketersediaanya meningkat akan di serap oleh tanaman dan akan memberikan efek negative kepada kehidupan manusia. Banyak usaha yang telah dilakukan dalam menangani pencemaran logam berat ini dan pemberian biochar merupakan solusi yang sangat menjanjikan, karena biochar memiliki potensi dengan luas permukaan yang besar, morfologi yang sangat porous serta gugus fungsionalnya yang berpotensi untuk mengurangi bioavailabilitas dan pelindian logam berat melalui adsorpsi dan reaksi fisikokimia lainnya dan juga dapat meningkatkan kesuburan tanah dengan perbaikan sifat sifat tanah. Biochar merupakan bahan basa yang dapat meningkatkan pH tanah dan berkontribusi terhadap stabilisasi logam berat. Aplikasi biochar untuk perbaikan dari tanah yang tercemar logam berat dapat memberikan solusi baru untuk masalah polusi tanah. Tulisan ini memberikan gambaran tentang pemanfaatan biochar dalam mengurangi mobilitas dan bioavailibiltas logam berat pada tanah tercemar
\end{abstract}

Kata kunci: biochar, remediasi, logam berat, soil contaminated

\section{PENDAHULUAN}

Pencemaran lingkungan merupakan isu yang paling menonjol saat ini, seiring dengan peningkatan jumlah pabrik pabrik yang bertujuan memenuhi kebutuhan penduduk yang semakin hari terus bertambah. Pabrik- pabrik tersebut menghasilkan limbah yang cukup besar, dan bila tidak di kelola dengan baik dan bertanggung akan memberikan efek negatif kepada lingkungan (Zhang et al. 2013). Menurut undang- undang lingkungan no.4 tahun 1982 pencemaran adalah masuknya atau di masukkannya makhluk hidup, zat, energi dan/ atau komponen lain ke dalam lingkungan, dan/ atau berubahnya tatanan lingkungan oleh kegiatan manusia atau proses alam, sehingga kualitas lingkungan turun sampai ke tingkat tertentu yang menyebabkan lingkungan menjadi kurang atau tidak dapat berfungsi lagi sesuai dengan peruntukannya (UU Repulik Indonesia No.4 tahun 1982)

Limbah yang dihasilkan oleh pabrik mengandung berbagai unsur yang berbahaya bagi bagi kehidupan manusia, salah satu diantaranya adalah logam berat. Logam berat secara alami sudah ada di dalam tanah dan tidak dapat teregradasi, dapat menetap di tanah dan badan air untuk waktu yang lama, sehingga akan terus meningkat dari waktu ke waktu (Govindasamy et.al 2011) Akumulasi logam yang ada pada tanah yang dapat mengakibatkan penurunan aktivitas mikroba tanah, kesuburan tanah, dan kualitas tanah secara keseluruhan, dan penurunan hasil dan masuknya bahan beracun ke rantai makanan (Kurnia et al. 2009, Atafar et al. 2010). Tanah dan air merupakan dua komponen yang menjadi sasaran pencemaran, bila tanah dan air tercemar logam berat maka logam berat akan masuk ke dalam rantai makanan dan membentuk jaring-jaring makanan dan akhirnya menuju kepada manusia sebagai konsumen universe sehingga menimbulkan berbagai macam penyakit pada manusia khususnya ganguan pada system syaraf (Sudarmaji, 2006).

Upaya untuk membersihkan daerah tercemar dengan penerapan strategi rehabilitasi lingkungan umumnya sangat mahal (Onrizal, 2005)), sehingga penting untuk mengembangkan strategi yang murah dan ramah lingkungan. Pengunaan tanaman sebagai 
agen dalam meremediasi logam berat pun pun telah di kembangkan pada berbagai jenis logam berat dengan harapan dapat meremediasi daerah tercemar dengan biaya yang relative murah (Brown et al 1995, Sal et 1995, Hidayat, 2011a, Ali et al. 2013) melahirkan filosofi "phytoextraction"dalam konsep yang lebih luas dari "fitoremediasi" (Kumar et al. 1995, Ali et al. 2013). Menggunakan kapasitas bioakumulasi kelompok tanaman tertentu dan dapat memberikan cara yang efektif untuk menghilangkan logam berat dari tanah yang tercemar (Grispen et al. 2006; Salido et al. 2003). Untuk satu setengah dekade terakhir, penelitian telah dilakukan pada berbagai spesies tanaman dalam kaitannya dengan phytoextraction logam dari tanah yang tercemar. Namun, keterbatasan utama dari phytoextraction adalah ketergantungan kepada kompleksasinya dengan koloid liat dan bahan organic dalam mengurang ketersediaan logam. Oleh karena itu, kunci sukses fitoremediasi logam berat pada tanah yang tercemar terletak pada optimalisasi praktek pengelolaan tanah dan hara untuk meningkatkan ketersediaan logam berat yang akan di jerap tanaman. Meskipun demikian, kebanyakan studi fitoremediasi membatasi diri untuk menggunakan tanaman pangan sebagai tumbuhan hiperakumulator (Zhang, et al 2013).

Perkembangan terbaru penanganan tanah yang tercemar dengan logam berat adalah dengan menggunakan biochar, biochar merupakan biomassa organik yang mengalami proses termolisis dan dapat dibuat dengan skala yang sederhana dapat di kembangkan untuk mengatasi permasalah lingkungan tercemaran hingga level terendah seperti pada petani. biochar memiliki area permukaan besar, dan kapasitas yang tinggi untuk menyerap logam berat dapat berpotensi digunakan untuk mengurangi bioavailabilitas dan pelindian logam berat dan juga polutan organik dalam tanah melalui adsorpsi dan lainnya reaksi fisikokimia (Park, 2011). Biochar biasanya merupakan basa bahan yang dapat meningkatkan $\mathrm{pH}$ tanah dan berkontribusi terhadap stabilisasi logam berat. Aplikasi biochar untuk perbaikan dari tanah yang tercemar dapat memberikan solusi baru untuk masalah polusi tanah.

\section{SUMBER - SUMBER LOGAM BERAT YANG MENCEMARI TANAH}

Logam berat secara secara alami sudah berada di alam dan tersingkap karena proses pelapukan, atau dari letusan gunung merapi dapat memberikan kontribusi kepada alam (Suhendrayatna, 2001) tetapi hal ini bila tidak mengalami perubahan yang mendasar pada siklus alamiahnya yaitu terkaitan kepada rantai makan tidak akan menimbulkan efek toksisitas pada manusia. (USDA NRCS, 2000).

Tabel 1. Kandungan logam berat secara alamiah $(\mu \mathrm{g} / \mathrm{g})$

\begin{tabular}{ccc}
\hline Logam & Kandungan (Rataan) & Kisaran Non Populasi \\
$\mathrm{As}$ & 100 & $5-3000$ \\
$\mathrm{Co}$ & 8 & $1-4$ \\
$\mathrm{Cu}$ & 20 & $2-300$ \\
$\mathrm{~Pb}$ & 10 & $2-200$ \\
$\mathrm{Zn}$ & 050 & $10-300$ \\
$\mathrm{Cd}$ & 0.06 & $0.05-0.7$ \\
$\mathrm{Hg}$ & 0.03 & $0.01-0.3$ \\
\hline
\end{tabular}

(Alloway, 1995)

Notohadiprawiro (1993) mengatakan bahwa sebab masuknya logam berat kedalam lingkungan hidup adalah:

1. Longgokan alami di dalam bumi tersingkap, sehingga berada di permukaan bumi

2. Pelapukan batuan yang mengandung logam berat yang melonggokkan logam berat secara residual di dalam saprolit dan selanjutnya berada di dalam tanah;

3. Penggunaan bahan alami untuk pupuk atau pembenah tanah (soil conditioner)

4. Pembuangan sisa dan limbah pabrik serta sampah .
Tanah secara alamiah mengandung logam berat, sebagian logam berat tersebut berperan dalam proses fisologis tanaman seperti $\mathrm{Fe}, \mathrm{Cu}$, $\mathrm{Zn}$ dan $\mathrm{Ni}$, tetapi dengan jumlah yang relatif sangat sedikit, bila berlebih akan memberikan efek tosisitas kepada tanaman, tetapi $\mathrm{Cd}$ dan $\mathrm{Pb}$ sangat bercun dan sampai saat ini belum di ketahui perananya bagi tanaman, kedua unsur ini merupakan pencemar kimia utama dalam lingkungan dan sangat beracun bagi tumbuhan, hewan dan manusia (Mangel and Kirkby, 1987) 
Tabel 2. Jenis- jenis batuan induk pembentuk tanah yang mengandung logam berat $\mathrm{Pb}$

\begin{tabular}{lc}
\hline \multicolumn{1}{c}{ Jenis Batuan } & $\mathrm{Pb}$ \\
\hline Ultra Basalt & $1-4$ \\
Basalt & $3-6$ \\
Granit & $18-24$ \\
Sabs dan Liat & $20-23$ \\
Sabs Hitam & $20-30$ \\
Pasir & $10-12$ \\
Kapur & $5-9$ \\
\hline
\end{tabular}

(Alloway, 1995)

Pemasok logam berat pada tanah pertanian antara lain bahan agrokimia melalui pupuk sintetik dan pestisida. Pemupukan kimia terbukti telah meningkatkan keberadaan logam berat pada tanah (Parkpian et al. 2003; Atafar et al. 2008)

Tabel 3. Konsentrasi Kadmium setelah pemberian pupuk 1 tahun

\begin{tabular}{|c|c|c|c|c|c|}
\hline \multirow[t]{3}{*}{ Sub area } & \multirow[t]{3}{*}{ Nomor } & \multicolumn{4}{|l|}{ Kadmium } \\
\hline & & \multicolumn{2}{|c|}{ Sebelum Pengolahan } & \multicolumn{2}{|c|}{ Setelah Pemanenan } \\
\hline & & Range & Mean \pm SD & Range & Mean \pm SD \\
\hline A & 9 & $1.15-1.50$ & $1.34 \pm 0.10$ & $1.40-1.68$ & $1.55 \pm 0.09$ \\
\hline B & 10 & $1.33-1.55$ & $1.45 \pm 0.06$ & $1.45-1.73$ & $1.60 \pm 0.08$ \\
\hline $\mathrm{C}$ & 10 & $1.23-1.55$ & $1.42 \pm 0.10$ & $1.40-1.73$ & $1.52 \pm 0.10$ \\
\hline $\mathrm{D}$ & 11 & $1.30-1.43$ & $1.36 \pm 0.04$ & $1.45-1.73$ & $1.59 \pm 0.08$ \\
\hline Total & 40 & $1.15-1.55$ & $1.39 \pm 0.09$ & $1.40-1.73$ & $1.57 \pm 0.09$ \\
\hline
\end{tabular}

(Atafar et al. 2008)

Tabel 4. Konsentrasi Timbal setelah pemberian pupuk 1 tahun

\begin{tabular}{|c|c|c|c|c|c|}
\hline \multirow[t]{3}{*}{ Sub area } & \multirow[t]{3}{*}{ Nomor } & \multicolumn{4}{|l|}{ Timbal } \\
\hline & & \multicolumn{2}{|c|}{ Sebelum pengolahan } & \multicolumn{2}{|c|}{ Setelah Pemanenan } \\
\hline & & Range & Mean \pm SD & Range & Mean \pm SD \\
\hline $\mathrm{A}$ & 9 & $1.80-6.05$ & $3.59 \pm 1.30$ & $6.83 \pm 12.85$ & $8.75 \pm 1.7$ \\
\hline B & 10 & $1.60-5.08$ & $3.60 \pm 1.20$ & $3.35 \pm 07.95$ & $5.93 \pm 1.3$ \\
\hline $\mathrm{C}$ & 10 & $2.80-5.03$ & $4.00 \pm 0.77$ & $2.75 \pm 08.60$ & $5.84 \pm 1.7$ \\
\hline $\mathrm{D}$ & 11 & $2.75-6.05$ & $3.51 \pm 0.97$ & $3.70 \pm 12.85$ & $7.84 \pm 2.8$ \\
\hline Total & 40 & $1.60-6.05$ & $3.68 \pm 1.07$ & $2.75 \pm 12.85$ & $7.07 \pm 2.3$ \\
\hline
\end{tabular}

(Atafar et al. 2008)

Tabel 5. Konsentrasi Arsenik setelah pemberian pupuk 1 tahun

\begin{tabular}{llllll}
\hline Sub area & Nomor & \multicolumn{4}{l}{ Arsenik } \\
\cline { 3 - 6 } & & \multicolumn{2}{l}{ Sebelum pengolahan } & \multicolumn{2}{l}{ Setelah Pemanenan } \\
\cline { 3 - 6 } & & $2.05-07.30$ & $4.14 \pm 1.8$ & $9.10-15.33$ & $12.10 \pm 2.4$ \\
A & 9 & $1.85-09.85$ & $4.88 \pm 2.2$ & $10.20-18.98$ & $14.22 \pm 2.8$ \\
B & 10 & $1.58-09.85$ & $4.53 \pm 2.5$ & $5.89-15.15$ & $11.48 \pm 3.4$ \\
C & 10 & $2.15-11.55$ & $3.86 \pm 2.6$ & $9.25-26.40$ & $12.79 \pm 4.9$ \\
D & 11 & $1.58-11.55$ & $4.34 \pm 2.3$ & $5.89-26.40$ & $12.66 \pm 3.6$ \\
Total & 40 & & & & \\
\hline
\end{tabular}

(Atafar et al. 2008)

Pemanfatan logam berat Arsenik (Cu), Tembaga $(\mathrm{Cu})$, Timbal dan Merkuri $(\mathrm{Hg})$ pada berbagai jenis pestisida juga terbukti memberikan kontribusi kepada peningkatan konsentrasi nya pada tanah dan tanaman (Ogunlade, 2010). 
Tabel 5. Kandungan Logam berat pada tanah akibat pemberian pestida di kawasan Cross River, Nigeria

\begin{tabular}{|c|c|c|c|c|c|c|c|c|}
\hline \multirow{2}{*}{$\begin{array}{l}\text { Lokasi } \\
\text { Sampel } \\
\text { Ikom }\end{array}$} & \multicolumn{3}{|l|}{ Jenis lahan } & \multicolumn{5}{|c|}{ Kadar Logam } \\
\hline & & $\mathrm{Pb}$ & $\mathrm{Cr}$ & $\mathrm{Ni}$ & Co & $\mathrm{Se}$ & $\mathrm{Cd}$ & As \\
\hline 1. & Grass field & 0.61 & 1.22 & 0.34 & 0.52 & 0.11 & 0.03 & 0.02 \\
\hline 2. & Makota & 0.63 & 1.07 & 0.30 & 0.42 & 0.18 & 0.04 & 0.02 \\
\hline 3 . & Okundi 1 & 0.64 & 0.93 & 0.32 & 0.54 & 0.13 & 0.05 & 0.02 \\
\hline 4. & Okundi 2 & 0.64 & 1.01 & 0.42 & 0.61 & 0.12 & 0.04 & 0.02 \\
\hline 5. & Yahunde & 0.76 & 1.02 & 0.24 & 0.43 & 0.09 & 0.03 & 0.02 \\
\hline 6. & Okundi forest & 0.72 & 1.10 & 0.34 & 0.59 & 0.11 & 0.03 & 0.01 \\
\hline \multicolumn{9}{|l|}{ Etung } \\
\hline 7 & Strabag & 0.76 & 1.01 & 0.34 & 0.60 & 0.10 & 0.03 & 0.02 \\
\hline 8 & 3 corner 1 & 0.61 & 0.93 & 0.27 & 0.53 & 0.13 & 0.04 & 0.02 \\
\hline 9 & 3 corner 2 & 0.59 & 0.88 & 0.25 & 0.54 & 0.10 & 0.03 & 0.01 \\
\hline 10 & Ajassor & 0.71 & 1.01 & 0.36 & 0.54 & 0.10 & 0.05 & 0.02 \\
\hline 11 & Bendegel & 0.86 & 0.99 & 0.36 & 0.59 & 0.07 & 0.02 & 0.01 \\
\hline 12 & Ajassor forest & 0.74 & 1.02 & 0.41 & 0.61 & 0.11 & 0.05 & 0.02 \\
\hline \multicolumn{9}{|l|}{ Boki } \\
\hline 13 & Biakwan 1 & 0.65 & 1.11 & 0.34 & 0.59 & 0.09 & 0.03 & 0.01 \\
\hline 14 & Biakwan 2 & 0.82 & 0.98 & 0.23 & 0.40 & 0.11 & 0.04 & 0.02 \\
\hline 15 & Biakwan 3 & 0.61 & 1.31 & 0.30 & 0.49 & 0.10 & 0.03 & 0.02 \\
\hline 16 & Boki forest & 0.50 & 1.03 & 0.31 & 0.58 & 0.11 & 0.03 & 0.02 \\
\hline
\end{tabular}

(Ogunlade et al. 2011)

Bidang Industri memainkan peranan yang besar sebagai sumber pencemaran bila limbah tidak dikelola dengan baik dan bertangung jawab, dan banyak dilaporkan terjadi pencemaran lahan pertanian khususnya daerah yang berhampiran dengan pabrik (Rogan et al. 2009; Arao et al. 2010; Machiwa,
2010; Muhammed et al. 2011). Pencemaran yang diakibatkan oleh industri didaerah pertanian khususnya lahan sawah, logam berat tidak hanya terkonsentrasi pada tanah, akar, daun tetapi juga pada gabah yang dihasilkan dan ini sangat berbahaya bila terdistribusi kepada masyarakat (Satpathy et al. 2014)

Tabel 6. Rata- rata konsentrasi logam berat pada tanah dan beberapa bagian tanaman Padi

\begin{tabular}{lllll}
\hline $\begin{array}{c}\text { Logam } \\
\text { berat }\end{array}$ & \multicolumn{1}{c}{ Tanah } & \multicolumn{1}{c}{ Akar } & \multicolumn{1}{c}{ Daun } & Gabah \\
\hline $\mathrm{Pb}$ & & & & \\
$\mathrm{Cd}$ & $0.3 \pm 0.4-19.8 \pm 1.3$ & $3.6 \pm 0.3-5.3 \pm 0.04$ & $0.3 \pm 0.01-1.2 \pm 0.01$ & $0.01 \pm 0.001-1 \pm 0.02$ \\
$\mathrm{Cu}$ & $0.03 \pm 0.004-0.6 \pm 0.04$ & $0.11 \pm 0.08-0.2 \pm 0.04$ & $0.2 \pm 0.01-0.3 \pm 0.01$ & $0.02 \pm 0.001-0.05 \pm 0.002$ \\
$\mathrm{Cr}$ & $1.3 \pm 0.01-7.8 \pm 0.3$ & $0.2 \pm 0.02-0.5 \pm 0.04$ & $0.04 \pm 0.08-0.3 \pm 0.03$ & $0.1 \pm 0.008-0.3 \pm 0.01$ \\
$\mathrm{Mn}$ & $12.5 \pm 0.2-53.9 \pm 1.5$ & $0.6 \pm 0.02-1.7 \pm 0.04$ & $0.4 \pm 0.01-0.9 \pm 0.04$ & $0.1 \pm 0.02-0.6 \pm 0.01$ \\
$\mathrm{Zn}$ & $3.8 \pm 1.7-33.8 \pm 1.3$ & $4.7 \pm 0.9-121.9 \pm 0.3$ & $25 \pm 2.8-32.9 \pm 1.9$ & $5.6 \pm 0.04-7.5 \pm 0.03$ \\
\hline
\end{tabular}

(Satpathy et al. 2014)

Pencemaran yang terjadi dapat merusak ekosistem di lahan pertanian dan akhirnya mempengaruhi produksi dan (Gambar 1), seperti yang di laporkan oleh Suganda et al. (2003) di Bandung Kecamatan Rancaekek oleh limbah industri tekstil yang mencemari sungai dan mengalir ke sawah sawah petani mempengaruhi fisiologis tanaman dan akhirnya menurunkan produktifitas lahan (Gambar 1), tetapi yang lebih membahayakan adalah terjadinya pencemaran lahan sawah tetapi tidak mempengaruhi produktifitas lahan hal ini terjadi karena padi adalah tumbuhan yang mempunyai kemampuan sebagai tanaman hiperakumulator (Noriharu dan Tomohito, 2002; Yang et al.2007) pada beberapa taraf $\mathrm{Pb}$ seperti yang terjadi di Tanjung Morawa (Hidayat, 2013) (Gambar 2), padi yang di hasilkan kemudian akan di konsumsi oleh manusia dan akan memberikan ganguan pada 


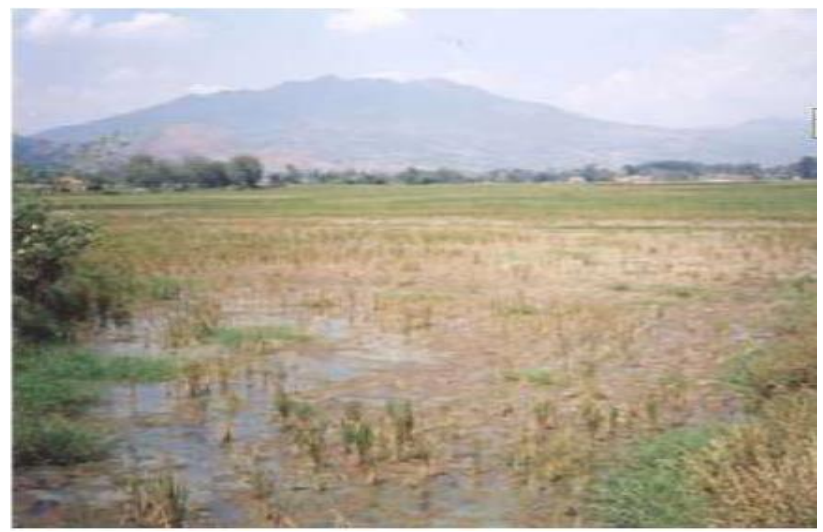

Gambar.1. Pencemaran mematikan tanaman padi dan menurunkan produktifitas lahan ( Kurnia, 2009)

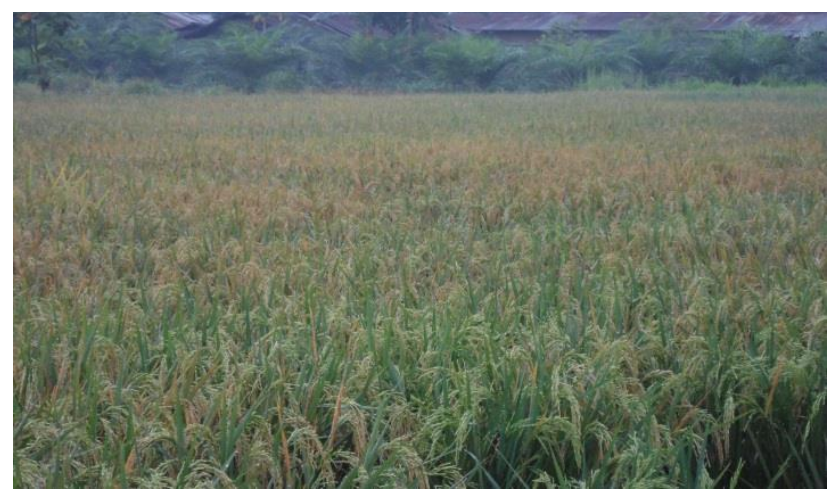

Gambar 2. Pencemaran tidak mempengaruhi produktifitas lahan ( Hidayat, 2013)

\section{MEKANISME BIOCHAR DALAM MEREMEDIASI TANAH TERCEMAR LOGAM BERAT}

Logam berat memiliki sifat tidak biodegradable, dan dapat bertahan untuk waktu yang lama pada tanah yang tercemar, untuk menghilangkanya membutuhkan waktu yang relative lama dan relative sangat mahal (Cui dan Zhang 2004). Stabilisasi logam berat secara in situ dapat dilakukan dengan menambahkan amandemen tanah yang umum digunakan seperti kapur dan kompos dalam upaya untuk mengurangi bioavailabilitas logam dan meminimalkan penyerapannya oleh tanaman
(Komarek et al. 2013). Biochar memiliki kemampuan menstabilkan logam berat pada tanah yamg tercemar dengan menurunkan secara nyata penyerapan logam berat oleh tanaman dan dapat meningkatkan kualitasnya dengan memperbaiki sifat sifat fisik kimia dan biologi tanah (Ippolito et al. 2012; Komarek et al. 2013) Oleh karena itu, penerapan biochar berpotensi untuk dapat memberikan solusi baru untuk perbaikan dari tanah yang tercemar oleh logam berat. Stabilisasi logam berat dalam tanah dengan penerapan biochar dapat melibatkan sejumlah mekanisme mungkin, karena diilustrasikan pada Gambar. 1 (Lu et al. 2012).

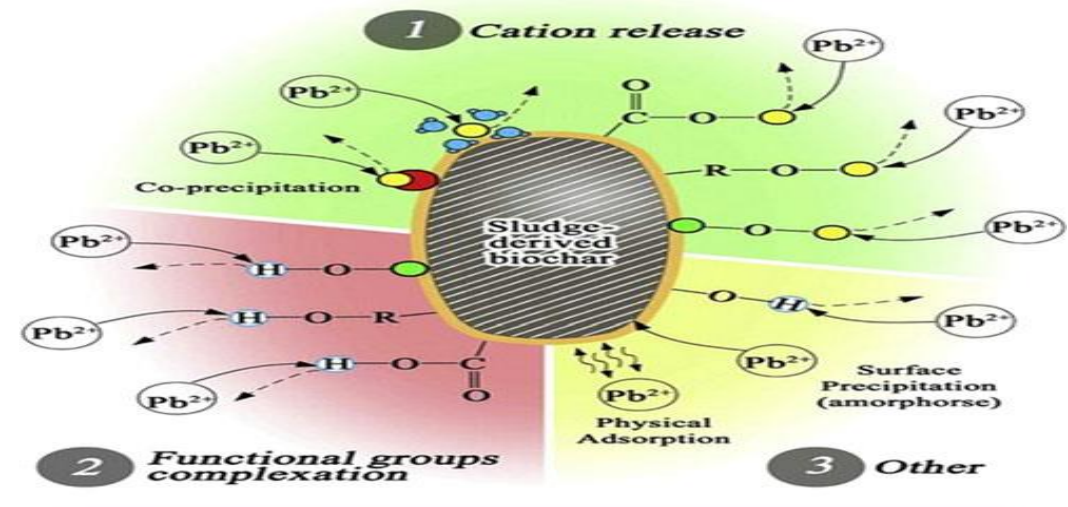

$\mathrm{Ca}(11) / \mathrm{Ca}^{2+}, \mathrm{K}(1) / \mathrm{K}$, , Mg(II)/Mg $/ \mathrm{Mg}^{2+}, \mathrm{Na}(1) / \mathrm{Na}$

$\mathrm{PO}_{4}{ }^{3}, \mathrm{SiO}_{4}^{2-}, \mathrm{CO}_{3}{ }^{2}$
Fe,

Gambar 3. Gambaran mekanisme penjerapan logam berat oleh Biochar (Lu et al. 2012) 
Lu et al (2012) pada gambar di atas memberikan contoh mekanisme penyerapan $\mathrm{Pb}^{2+}$ oleh lumpur biochar yang dapat mencakup

1. Bursa $\mathrm{Pb}^{2+}$ dengan $\mathrm{Ca}^{2+}, \mathrm{Mg}^{2+}$, dan kation lainnya yang ada pada biochar, yang terpresipitasi bersama dan kompleksasi innersphere dengan kompleks materi humat dan oksidaoksida mineral dari biochar;

2. Kompleksasi permukaan logam berat dengan gugus fungsional yang berbeda, dan kompleksasi dengan mineral oksida hidroksil bebas dan mengendap pada permukaan lainnya;

3. Fisik adsorpsi innersphere dan presipitasi permukaan yang berkontribusi terhadap stabilisasi $\mathrm{Pb} 2$

Dalam kasus tanah tercemar yang bereaksi masam, jenis biochars dan kation tukar ( $\mathrm{Na}, \mathrm{Mg}, \mathrm{K}$, dan $\mathrm{Ca}$ ) memegang peran untuk membebaskan beberapa ini kation selama proses penjerapan dengan logam berat, dan sehingga dapat memperkaya proses stabilisasi. Mekanisne utama yang bertanggung jawab atas proses penjerapan logam berat menurut Lu et al (2012) adalah pertukaran logam berat dengan $\mathrm{Ca}^{2+}, \mathrm{Mg}^{2+}$, dan kation lainnya $\left(\mathrm{Na}^{+}\right.$dan $\left.\mathrm{K}+\right)$ yang ada pada lumpur biochar. Namun, sangat sedikit kontribusi kation monovalent $(\mathrm{Na}+$ dan $\mathrm{K}+$ ) dalam proses pertukaran kation logam berat Oleh karena itu, dapat dibayangkan bahwa di bawah situasi lapangan yang sebenarnya, mekanisme penyerapan untuk tanah tercemar logam berat dengan pemberian biochar dapat tergantung pada jenis tanah dan keberadaan kation pada tanah dan biochar, dengan demikian implikasi untuk perbaikan di tanah yang tercemar bisa bervariasi ( $\mathrm{Lu}$ et al. 2012)

Komponen lain yang memegang peranan penting adalah keberadaan mineral seperti fosfat dan karbonat dalam aplikasi biochar memainkan peran penting dalam stabilisasi berat logam dalam tanah karena garam-garam ini dapat berikatan dengan berat logam dan mengurangi bioavailabilitas mereka (Cao et al. 2009). Cao dan Harris (2010) mengusulkan bahwa mekanisme utama biochar yang efektif untuk menahan $\mathrm{Pb}$ adalah dengan presipitasi $\mathrm{Pb}$ fosfat. Umumnya, selama pembuatan biochar, $\mathrm{P}, \mathrm{Ca}$, dan $\mathrm{Mg}$ yang dapat terlarut meningkat ketika dipanaskan sampai $200^{\circ} \mathrm{C}$, tapi menurun pada suhu yang lebih tinggi, mungkin karena peningkatan pembentukan kristalisasi Ca-Mg-P, seperti dibuktikan dengan pembentukan whitlockite
(Ca, Mg) 3 (PO4) 2 saat suhu pirolisis meningkat menjadi $500 \circ \mathrm{C}$, sehingga memfasilitasi pengendapan $\mathrm{Pb}$ (Cao dan Harris 2010).

Alkalinitas biochar juga mengambil peran pada presipitasi logam berat di tanah. Chan dan Xu (2009) melapo $r$ dalam literatur bahwa rata- rata nila $\mathrm{pH}$ biochar dari berbagai bahan baku adalah pH 8.1. Dengan bahan baku yang sama, nilai $\mathrm{pH}$ biochar akan meningkat seiring dengan peningkatan suhu pirolisis karena peningkatan kadar abu di biochar. Oleh karena itu, sebagian besar biochars adalah bahan alkali dan memiliki efek pengapuran, yang dapat berkontribusi pada pengurangan mobilitas dari logam berat dalam tanah yang tercemar (Sheng et al.2005; Wu et al. 2012). Namun, kemampuan adsorpsi dari jenis yang sama dari biochar bervariasi dengan berbagai jenis logam berat.

\section{BIOCHAR DAN MOBILITAS LOGAM BERAT}

Tanaman menyerap logam berat dalam bentuk radikal (bebas) yang mempunyai mobilitas yang tinggi, aplikasi biochar dapat mengurangi mobilitas logam berat ditanah yang tercemar sehingga tidak dapat diserap oleh tanaman kerena sudah tidak tersedia bagi tanaman. Penelitian telah menunjukkan bahwa biochar yang berasal dari bambu dapat menjerap $\mathrm{Cu}, \mathrm{Hg}, \mathrm{Ni}$, dan $\mathrm{Cr}$ dari baik tanah dan air, dan $\mathrm{Cd}$ dalam tanah tercemar (Skjemstad et al. 2002; Cheng et al. 2006). Cao et al. (2009) melaporkan bahwa biochar yang berasal dari kotoran sapi pada suhu pyrolyzed $200^{\circ} \mathrm{C}$ lebih efektif dalam menjerap $\mathrm{Pb}$ dari biochar dihasilkan pada $350{ }^{\circ} \mathrm{C}$, karena $\mathrm{C}$ biochar $200^{\circ}$ memiliki konsentrasi fosfat yang lebih tinggi.

Jiang et al. (2012) juga menyebutkan bahwa pemakaian biochar jerami padi dapat mengurangi mobilitas radikal $\mathrm{Pb}, \mathrm{Cd}$ pada tanah ultisol yang ber-pH rendah dan penyerapan non elektrostatik sangat berperan pada jenis biochar ini. Debela et al (2012) menggunakan biochar dari kayu yang dapat mengurangi mobilitas Zn dan Cd sampai $90 \%$. Berdasarkan keterangan di atas dapat dilihat bahwa biochar tidak secara umum dapat digunakan pada setiap pencemaran dengan hasil maksimal, kondisi pirolisis juga mempengaruhi kualitas biochar, oleh karena itu pemanfaatan biochar sebagai amandemen untuk remediasi tanah tercemar logam berat harus memperhitungkan jenis logam, jenis biochar 
dan produksi biochar pada suhunya yang tertentu.

Tabel 7. Pengaruh pemberian biochar pada mobilitas logam berat pada tanah

\begin{tabular}{|c|c|c|c|c|}
\hline Sumber biochar & $\begin{array}{l}\text { Suhu proses } \\
\left({ }^{\circ} \mathrm{C}\right)\end{array}$ & $\begin{array}{l}\text { Jenis } \\
\text { logam }\end{array}$ & Pengaruh & Referensi \\
\hline Bambu & $\begin{array}{l}\text { Tidak } \\
\text { disebutkan }\end{array}$ & $\mathrm{Cd}$ & $\begin{array}{l}\text { Menjerap } 75 \% \mathrm{Cd} \text { dalam } \\
12 \text { hari dengan efek } \\
\text { kombinasi elektrokinetik }\end{array}$ & Ma et al. (2007) \\
\hline Hardwood & 450 & $\begin{array}{l}\mathrm{As}, \mathrm{Cd}, \\
\mathrm{Cu}, \mathrm{Zn}\end{array}$ & $\begin{array}{l}\text { Mengurangi mobilitas } \\
\text { logam pada pori air } \\
\text { tanah, metode pencucian }\end{array}$ & Beesley et al.(2010) \\
\hline Kayu & 200 dan 400 & $\mathrm{Cd}, \mathrm{Zn}$ & Mengurangi $90 \% \mathrm{Zn}, \mathrm{Cd}$ & Debela et al. (2012) \\
\hline Jerami padi & $\begin{array}{l}\text { Tidak } \\
\text { disebutkan }\end{array}$ & $\begin{array}{l}\mathrm{Cu}, \mathrm{Pb} \\
\mathrm{Cd}\end{array}$ & $\begin{array}{l}\text { Efektif mengurangi } \\
\text { konsentrasi radikal } \\
\mathrm{Cu}, \mathrm{Pb}, \mathrm{Cd}\end{array}$ & Jiang et al. (2012) \\
\hline Jerami padi & 300 & $\mathrm{~Pb}$ & $\begin{array}{l}\text { Meningkatkan penyerap } \\
\mathrm{Pb} \text { non elektrotatik }\end{array}$ & Jiang et al. (2012) \\
\hline
\end{tabular}

\section{BIOCHAR DAN BIOAVAILABITAS LOGAM BERAT}

Bioavailabilitas mempunyai beberapa pengertian oleh para ahli diantaranya adalah :

- Sejumlah senyawa beracun yang ada di dalam tanah atau fraksi kontaminan yang dapat diambil oleh mahluk hidup dan menyebabkan keracunan (Prokop dan Holoubek, 2001)

- Sejumlah logam tertentu yang dapat diambil oleh tanaman atau mikroorganisme sehingga menimbulkan respon yang dapat diamati $(\mathrm{Ok}$ et al.2004)

- Ilmu mikrobiologi lingkungan mendefinisikan bioavailabilitas sebagai fraksi kontaminan yang merupakan aksesibilitas bahan kimia bagi organisme hidup untuk melakukan asimilasi, degradasi, dan ekspresi ekotoksikologi (Naidu et al. 2008).
- Bioavailabilitas mengacu kepada fraksi dosis kontaminan yang diserap oleh tubuh ke dalam system sirkulasi sistemik (Health Protection Agency, 2009)

- Bioavailabilitas didefenisikan sebagai bagian dari total konsentrai kimia yang tersedia untuk sel-sel reseptor (tanah, mikroba dan lainnya) (Sarwar et al 2010)

Bioavailabilitas logam berat dapat menunjukkan besarnya potensi masuknya logam berat ke dalam rantai makanan. Sejumlah penelitian yang telah dilakukan menunjukkan bahwa pemberian biochar efektif dalam imobilisasi logam berat, sehingga dapat mengurangi ketersediaanya (bioavailabilitas) dan daya cemaran bila diserap oleh tumbuhan (phytotoxicity) logam berat (Tabel 8).

Tabel 8. Hasil beberapa penelitian tentang efek biochar pada tanah terkontaminasi logam berat

\begin{tabular}{|c|c|c|c|c|}
\hline Sumber & $\begin{array}{l}\text { Suhu } \\
\left({ }^{0} \mathrm{C}\right)\end{array}$ & $\begin{array}{c}\text { Logam } \\
\text { Pencemar }\end{array}$ & Efek & Referensi \\
\hline $\begin{array}{l}\text { Tangkai } \\
\text { kapas }\end{array}$ & 450 & $\mathrm{Cd}$ & $\begin{array}{l}\text { Mengurangi ketersedia Cd dalam Tanah } \\
\text { melalui penjerapan da presipitasi }\end{array}$ & Zhou et al. (2008) \\
\hline Kayu & 400 & As & Nyata mengurangi As pada daun Miscanthus & Hartley et al. (2009) \\
\hline $\begin{array}{l}\text { Sampah } \\
\text { Kebun } \\
\text { buahan }\end{array}$ & 500 & $\begin{array}{l}\mathrm{Cd}, \mathrm{Cr}, \\
\mathrm{Cu}, \mathrm{Ni}, \\
\mathrm{Pb}, \mathrm{Zn}\end{array}$ & Nyata mengurangi ketersediaan $\mathrm{Cd}, \mathrm{Pb}$ dan $\mathrm{Zn}$ & Fellet et al. (2011) \\
\hline $\begin{array}{l}\text { Jerami } \\
\text { Gandum }\end{array}$ & 550 & $\mathrm{Cd}$ & $\begin{array}{l}\text { Mengurangi serapan Cd pada bagian tanaman } \\
\text { padi dan nyata pada gabah }\end{array}$ & Cui et al. (2011) \\
\hline $\begin{array}{l}\text { Kotoran } \\
\text { ayam dan } \\
\text { sampah hijau }\end{array}$ & 550 & $\mathrm{Cd}, \mathrm{Cu}, \mathrm{Pb}$ & $\begin{array}{l}\text { Nyata mengurangi akumulasi } \mathrm{Cd}, \mathrm{Cu} \text { dan } \mathrm{Pb} \\
\text { pada Indian Mustard }\end{array}$ & Park et al.(2011) \\
\hline
\end{tabular}




\begin{tabular}{lllll}
\hline Jerami padi & $\begin{array}{l}\text { Tidak } \\
\text { disebu } \\
\text { tkan }\end{array}$ & $\mathrm{Cu}, \mathrm{Pb}, \mathrm{Cd}$ & $\begin{array}{l}\text { Nyata menurunkan konsentrasi radikal } \mathrm{Cu}, \mathrm{Pb} \\
\text { dan Cd pada tanah tercemar }\end{array}$ & Jiang et al (2012) \\
Kayu Oak & 400 & $\mathrm{~Pb}$ & $\begin{array}{l}\text { Mengurangi ketersedian Pb hingga 78.8\% } \\
\text { dengan nilai bioaccessibility 12.5\% }\end{array}$ & Ahmad et al. (2013) \\
\hline
\end{tabular}

Potensi penggunaan biochar untuk menghilangkan daya toksisitas logam berat pada limbah tambang telah di lakukan oleh banyak peneliti diantara; Fellet et al. (2011), dengan menggunakan biochar yang berasal dari sampah kebun di empat level pemberian biochar $(0 \%, 1 \%, 5 \%$, dan 10\%) pada limbah tambang). Hasilnya terjadi peningkatan $\mathrm{pH}$, tukar kation kapasitas, dan kapasitas daya pegang air meningkat seiring dengan peningkat jumlah biochar yang diberikan dan terjadi penurunan bioavailabilitas $\mathrm{Cd}, \mathrm{Pb}$, dan $\mathrm{Zn}$, dan $\mathrm{Cd}$ memiliki penurunan terbesar. Zhou et al. (2008) yang menggunakan biochar tangkai kapas untuk menghilang Cd-tercemar pada tanah dan mengurangi penyerapan $\mathrm{Cd}$ oleh kubis dan hasil menujukan bahwa biochar tangkai kapas dapat mengurangi bioavailabilitas tanah Cd melalui adsorpsi atau co-presipitasi.
Penggunaan biochar kotoran ayam dan biochar limbah daunan secara signifikan mengurangi $\mathrm{Cd}, \mathrm{Cu}$, dan $\mathrm{Pb}$ jerapan oleh sawi pengurangan ini terus meningkat seiring dengan peningkatan aplikasi biochar kecuali untuk konsentrasi $\mathrm{Cu}$,di tempat lain, sebuah studi yang dilakukan oleh Jiang et al. (2012) menunjukkan bahwa biochar jerami padi lebih efisien dalam imobilisasi $\mathrm{Cu}$ dan $\mathrm{Pb}$ dari $\mathrm{Cd}$. Cui et al. (2011), melaporan penggunaan biochar jerami gandum pada tanah terkontaminasi $\mathrm{Cd}$ di daerah Yipeng Jiangsu China, dengan dosis $0,20,40$ ton/ha pada penelitian lapangan 2 tahun berturut 2009-2010, mendapatkan hasil bahwa pengurangan konsentrasi $\mathrm{Cd}$ pada jaringan tanaman dan juga pada gabah dan nyata pada dosis 40 ton/ ha (C3) (Gambar 4.)

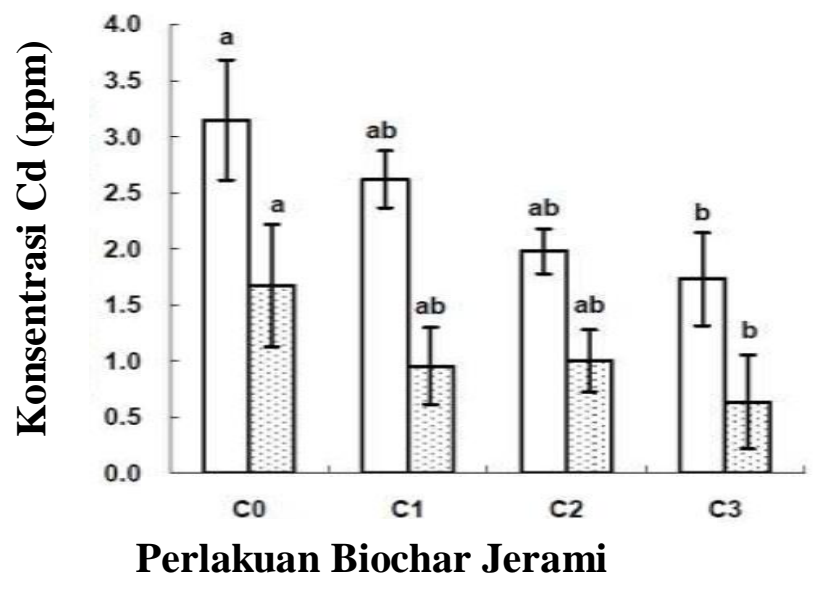

Gambar 4. Konsentrasi Cd pada beberapa pemberian biochar jerami gandum (Cui et al. 2011)

Pemanfaatan biochar pada tanah terkontaminasi adalah untuk menghilang keaktifan ion- ion logam berat, sehingga tidak masuk kedalam sistem rantai makanan pada manusia dan tidak membahayakan karena akan segera tercuci dan mengendap, dan hal ini sangat berhubungan dengan kualitas biochar yang dihasilkan, biochar yang diproduksi dengan suhu yang tinggi $\left(\geq 600{ }^{\circ} \mathrm{C}\right)$ umumnya memiliki luas permukaan yang tinggi baik untuk penjerapan secara fisik, tetapi mempunyai sedikit gugus fungsional dan kandungan hara yang rendah, tetapi sebaliknya biochar yang di bentuk dengan suhu 400-500 ${ }^{0} \mathrm{C}$ memiliki gugus fungsional yang beragam dan relative mengandung hara (Zhen et al. 2013). Uchimiya et al. (2010b) menyatakan bahwa Aplikasi biochar dapat meningkatkan $\mathrm{pH}$ tanah dan kation kapasitas tukar, dan kemudian meningkatkan imobilisasi logam berat dalam tanah. Ahmad et al. (2012) yang digunakan biochar kulit kerang, tulang sapi, untuk mengurangi toksisitas $\mathrm{Pb}$ di tanah lapangan tembak militer yang sangat tercemar di Korea dan hasilnya menurunkan Bioavailabilitas $\mathrm{Pb}$ pada tanah hingga $75,8 \%$ dengan. Peningkatan tanah $\mathrm{pH}$ dan kapasitas adsorpsi dianggap sebagai Mekanisme efek remediasi biochar tersebut. Sebagai contoh,bioavailabilitas $\mathrm{Pb}$ dalam tanah mengalami penurunan sebesar hingga 92,5\% dengan kulit kerang, karena adanya bahan kapur (Ahmad et al. 2012). 


\section{SIMPULAN}

Pencemaran merupakan resiko yang tidak dapat dihindari seiringan dengan adanya peningkatan jumlah penduduk dan usaha pemenuhan kehidupan yang banyak menghasilkan limbah. Banyak usaha yang telah dilakukan untuk mengurangi efek negatif dari limbah tersebut dan biochar merupakan bahan yang berpotensi untuk di aplikasi pada tanah tercemar. Biochar mempunyai kemampuan secara fisik dan kimia untuk menghilangkan keaktifan logam berat dan juga dapat mensuplay sejumlah hara, dan ini tergantung kepada teknik produksi biochar.

\section{DAFTAR PUSTAKA}

AraoT, Satoru I, Masaharu M, Kaoru A, Yuji M, Tomoyuki M, 2010. Heavy metal contamination of agricultural soil and countermeasures in Japan Paddy Water Environ (2010) 8:247-257 DOI 10.1007/s10333-010-0205-7

Ahmad M, Soo Lee S, Yang JE, Ro HM, Han Lee Y, Ok YS, 2012. Effects of soil dilution and amendments (mussel shell, cow bone, and biochar) on $\mathrm{Pb}$ availability and phytotoxicity in military shooting range soil. Ecotoxicol Environ Saf 79:225-231

Ali H, , Ezzat K, Muhammad AS, 2013. Phytoremediation of heavy metalsConcepts and applications Chemosphere 91 (2013) 869-881

Alloway BJ, 1995. Heavy Metals In Soils. Blackie academic Professional. London

Atafar Z, Alireza M, Jafar N, Mehdi H, Masoud Y, Mehdi A, Amir H M, 2008. Effect of fertilizer application on soil heavy metal concentration Environ Monit Assess (2010) 160:83-89 DOI 10.1007/s10661-008-0659-x

Beesley L, Moreno-Jiménez E, Gomez-Eyles JL, 2010. Effects of biochar and greenwaste compost amendments on mobility, bioavailability and toxicity of inorganic and organic contaminants in a multi-element polluted soil. Environ Pollut 158:2282-2287

Brown RA, Kercher AK, Nguyen TH, Nagle DC, Ball WP, 2006. Production and characterization of synthetic wood chars for use as surrogates for natural sorbents. Org Geochem 37:321-333

Cao XD, Harris W, 2010. Properties of dairymanure-derived biochar pertinent to its potential use in remediation. Bioresou Technol 101:5222-5228

Cao X, Ma L, Gao B, Harris W, 2009. Dairymanure derived biochar effectively sorbs lead and

atrazine. Environ Sci Technol 43:3285-3291

Cui L, Lianqing L, A feng Z, Genxing P, Dandan B, Andrew C, 2011. Biochar amendment greatly reduces rice $\mathrm{Cd}$ uptake in a contaminated paddy soil: A two year field Experiment. BioResources 6(3)2605-2618

Debela F, Thring RW, Arocena JM, 2012. Immobilization of heavy metals by copyrolysis of contaminated soil with woody biomass. Water Air Soil Pollut 223:1161-1170

Fellet G, Marchiol L, Delle Vedove G, Peressotti A, 2011. Application of biochar on mine tailings: effects and perspectives for land reclamation. Chemosphere 83:1262-1297

Govindasamy, C., Arulpriya, M., Ruban, P., Francisca, L.J., Ilayaraja, A., 2011. Concentration of heavy metals in seagrasses tissue of the Palk Strait, Bay of Bengal. Int. J. Environ. Sci. 2, 145-153.

Grispen V.M.J, H.J.M. Nelissen, J.A.C.Verlei. 2006.Phytoextraction with Brassia napus; a toll for sustainable management of heavy metalcontaminated soils. Environment pollution 144: 77-83

Health Protection Agency, 2009. Cadmium. HPA Contaminated Land Information Sheet.

Hidayat, B. 2011a. Skrining Tumbuhan Tumbuhan air Hiperakumulator. Kultura UMN Alwashliyah. Volume 20 September 2011.

Hidayat, B., 2013. Analisis Status Pb Pada lahan dan tanaman Padi di Daerah Pabrik Tanjung

Morawa Sumatera Utara, Belum di Publikasikan. Fakultas Pertanian Universitas Sumatera Utara

Ippolito JA, Laird DA, Busscher WJ (2012) Environmental benefits of biochar. J Environ Qual 41:967-972

Komárek M, Vaněk A, Ettler V (2013) Chemical stabilization of metals and arsenic in contaminated soils using oxides-a review. Environ Pollut 172:9-22

Kurnia U, H. Suganda, R. Saraswati, Nurjaya. 2009. Teknologi Pengendalian 
Pencemaran Lahan Sawah. http://balittaanah.litbang.deptan.go.i d/dokumentasi/buku/tanahsawah/tan ahsawah9.pdf

Jiang J, Ren-kou Xua, Tian-yu Jiang, Zhuo Li, 2012. Immobilization of $\mathrm{Cu}$ (II), $\mathrm{Pb}$ (II) and $\mathrm{Cd}(\mathrm{II})$ by the addition of rice straw derived biochar to a simulated polluted Ultisol. Journal of Hazardous Materials 229- 230 (2012) 145- 150

Lu H, Zhang YY, Huang X, Wang S, Qiu R, 2012. Relative distribution of $\mathrm{Pb} 2+$ sorption mechanisms by sludgederived biochar. Wat Res 46:854-862

Ma JW, Wang H, Luo QS, 2007. Movementadsorption and its mechanism of $\mathrm{Cd}$ in soil under combining effect of electrokinetics and a new type of bamboo charcoal. Environ Sci 28:1829-1834

Machiwa F, 2010. Heavy metal levels in paddy soils and rice (Oriza Sativa .L) from wetlands of lake Victoria Basin Tanzanian. Tanzanian Journal science Vol 36 (2010)

Mengel, K and Kirkby. 1987. Principle of Plant Nutrition. 4 th Edition. International Potash Institute. Bern

Mohammed As, Anil K, Reeta G, 2011. Heavy Metal Pollution: Source, Impact, and Remedies Environmental Pollution 20, DOI 10.1007/978-94-007-19149_1,(C) Springer Science+Business Media B.V. 2011

Naidu R, Semple KT, Megharaj M, Juhasz AL, Bolan NS, Gupta S,Clothier B, Schulin R, Chaney R, 2008. Bioavailability, definition, assessment and implications for risk assessment. In: Naidu R, et al. (eds) Chemical bioavailability in terrestrial environment. Elsevier, Amsterdam, pp 39-52. ISBN:978-0444-52

Namgay T, Singh B, Singh BP, 2010. Influence of biochar application to soil on the availability of $\mathrm{As}, \mathrm{Cd}, \mathrm{Cu}, \mathrm{Pb}$, and $\mathrm{Zn}$ to maize (Zea mays L.). J Aust Soil Res 48:638-647

Notohadiprawiro T, 2006. Logam Berat Dalam Pertanian.Seminar di PPKS, Medan 28 Agustus 1993, direpro. Jurusan Ilmu Tanah Gajah Mada, 2006.

Ogunlade M O, S.O.Agbeniyi, 2011. Impact of pesticides use on heavy metal pollution in cocao soil of Cross- River , Nigeria. African Journal of Agriculture Research Vol. 6(16) ,pp.3725-3728
Ok Y.S, H. Lee, J.J.H. Song, N. Chung, S. Lim and J.G. Kim, 2004. ChemicalCharacterization and Bioavailability of Cadmium in Artificial and Natural Contaminated Soils. Agric.Chem.Biotechnol. 47(3), 143-146

Onrizal, 2005. Restorasi lahan terkontaminasi logam berat. e- USU repository, 2005 Universitas Sumatera Utara

Park, J.H, Girish K. C, Nanthi S. B, Jae W C, Thammared C, 2011. Biochar reduces the bioavailability and phytotoxicity of heavy metals. Plant Soil (2011) 348:439-451. DOI 10.1007/s11104011-0948-y

Parkpian, P., Leong, S. T., Laortanakul, P., \& Thunthaisong, N, 2003. Regional monitoring of lead and cadmium contamination in a tropical grazing land site, Thailand. Environmental Monitoring and Assessment, 85(2), 157-173.

DOI:10.1023/A: 1023638012736.

Prokop dan Holoubek, 2001. The use of Microbial contact toxicity test for evaluating Cadmium Biovailibility in Soil. J. Soil \& sediment 1 (1)21-24

Rogan N, Todor S, Matej Dolenec, Goran Tasev, Tadej Dolenec, 2009. Heavy metal contamination of paddy soils and rice (Oryza sativa L.) from Kocani Field (Macedonia). Environ Geochem Health. 31: 439-541

Sarwar N. Saifullah, S.S. Malhi, M.H.Zia, A. Naeem, S. Bibi, G.Farid, 2010. Role of mineral nutrition in minimazing Cadmium in minimizing Cadmium accumulation by plants. J.Sci Food Agric 2010; 90:925-937

Satpathy D, M. Vikram R, Soumya P D, 2014. Risk Assessment of Heavy Metals Contamination in Paddy Soil, Plants, and Grains (Oryza sativa L.) at the East Coast of India. Volume 2014 (2014), Article ID 545473, $11 \quad$ pages http://dx.doi.org/10.1155/ $2014 / 545473$

Sheng GY, Yang YN, Huang MS, Yang K (2005) Influence of $\mathrm{pH}$ on pesticide sorption by soil containing wheat residue-derived char. Environ Pollut 134:457-463

Wu W, Yang M, Feng Q, McGrouther K, Wang H, Lu H, Chen Y, 2012. Chemical characterization of rice straw-derived 
biochar for soil amendment. Biom Bioene 47:268-276

Skjemstad JO, Reicosky DC, McGowan JA,Wilts AR (2002) Charcoal carbon in U.S. agricultural soils. Soil Sci Soc Am J 66:1249-1255

Cheng CH, Lehmann J, Thies JE, Burton SD, Engelhard MH, 2006. Oxidation of black carbon by biotic and abiotic processes. Organ Geochem 37:14771488

Cao XD, Ma LN, Gao B, Harris W, 2009 Dairy-manure derived biochar effectively sorbs lead and atrazine. Environ Sci Technol 43:3285-3291

Sudarmaji, J. Mukono, Corie, 2006. Toksikologi logam berat B3 dan dampaknya terhadap kesehatan. Jurnal Kesehatan Lingkungan, Vol. 2, No. 2 , Januari 134 2006:129 -142

Suganda H, D. Setyorini, H.Kusnadi, I. Saripin, Undang K, 2003. Evaluasi pencemaranlimbah industry untuk kelestarian sumberdaya lahan sawah. Hlm 203-221. Prosiding seminar Nasional multifungsi dan Konversi lahanpertanian.Pusat penelitian dan Pengembangan Tanah dan Agriklimat. Bogor

Suhendrayatna, 2001. Heavy metal bioremoval by microorganisms: a literature study. http://www.istecs.org/Publication/Japa $\mathrm{n} / 010211$.

Undang- Undang Repulik Indonesia, 1982Ketentuan- ketentuan pokok pengelolaan lingkungan hidup No.4/1982

Zhang X, Hailong W, Lizhi H, Kouping L, Ajit S, Jianwu L, N S. B, Jianchuan P, Huagang H, 2007. Using biochar for remediation of soils contaminated with heavy metals and organic pollutants. Environ Sci Pollut Res DOI 10.1007/s11356-013-1659-0

Zhang P, Sun H, Yu L, Sun T, 2013. Adsorption and catalytic hydrolysis of carbaryl and atrazine on pig manurederived biochars: impact of structural properties of biochars. J Hazard Mater 244-245:217-224

Zheng W, Guo MX, Chow T, Bennett DN, Rajagopalan N, 2010. Sorption properties of greenwaste biochar for two triazine pesticides. J Hazard Mater 181:121-126

Uchimiya M, Lima IM, Klasson KT, Wartelle LH ,2010. Contaminant immobilization and nutrient release by biochar soil amendment: roles of natural organic matter. Chemosphere 80:935-940

Zhou JB, Deng CJ, Chen JL, Zhang QS, 2008. Remediation effects of cotton stalk carbon on cadmium $(\mathrm{Cd})$ contaminated soil. Ecol Environ 17:1857-1860 